\title{
DIREITOS HUMANOS E DEMOCRACIA A experiência das comissóes da verdade no Brasil*
}

\section{Cristina Buarque de Hollanda}

Instituto de Estudos Sociais e Políticos da Universidade do Estado do Rio de Janeiro (Iesp-Uerj), Rio de Janeiro - RJ, Brasil.

E-mail: cristinabuarque@gmail.com.

DOI: $10.17666 / 339610 / 2018$

* Agradeço aos pareceristas anônimos que contribuíram com sua leitura atenta para o aprimoramento do artigo. Agradeço também, efusivamente, aos onze membros de Comissóes da Verdade, que foram generosos em me ceder tempo de suas agendas atribuladas para as entrevistas que compóem a principal matéria-prima desta pesquisa, autorizando a publicação dos relatos sob anonimato neste artigo. Sou ainda especialmente grata a Alexandre Werneck, precioso interlocutor à época dos primeiros passos deste trabalho, e Mariana Possas, que acompanhou esta trajetória de perto, com leituras sempre críticas, criativas e entusiasmadas. Mariana também conduziu a entrevista de um dos comissionados. Por fim, devo uma menção especial ao grupo de bravos e engajados estudantes que contribuíram com este trabalho em diferentes momentos. São eles: Amanda Evelyn Lima, Aparecido Silva, Arnaldo Lucas Pires Junior, Ana Carolina Santos, Caroline Caldas, Joyce Abbade, Lucas Burgos, Mayara Gonçalves, Natália Thaise Costa, Rafael Massena, Raul Galate Ribeiro e Silvana Telles. Partilho com eles as eventuais virtudes do artigo e deixo os problemas na minha conta exclusiva.

Artigo recebido em 13/05/2016

Aprovado em 14/06/2017

\section{Introdução}

"Os direitos humanos chegaram aqui porque eram uma categoria neutra”, afirmou uma importante militante pela igualdade racial na África do Sul em entrevista à autora deste artigo. $\mathrm{O}$ mundo que ela observava era o da transição do apartheid para a democracia, apoiada em uma delicada arquitetura institucional que manejava setores em ascensão e declínio políticos. Em meio a uma sociedade profundamente dividida por décadas de segregação racial, nascia um consenso mínimo em torno da ideia de que agentes do Estado não podiam matar, torturar, sequestrar ou desaparecer com pessoas. Era apenas isso que demandavam os direitos humanos, afinal.

Em substituição ao radicalismo de repertórios do socialismo, os direitos humanos eram articulados como utopia minimalista, esvaziada de política e voltada para a correção moral de sujeitos violentos. Eles 
chegavam na África do Sul - e em toda parte - como uma espécie de chão comum para a conversa entre personagens historicamente antagônicos. É certo que não cumpriram ali nem em qualquer outro lugar um percurso linear e imune a conflitos de entendimento e forma, mas se fizeram populares.

Segundo Samuel Moyn, foi a partir das décadas de 1970 e 1980 que os direitos humanos deixaram de ter uma existência meramente nominal em tratados e conferências internacionais. Fixaram-se no léxico de organizações internacionais, movimentos sociais, partidos e governos de diferentes vocaçóes políticas. Mais do que isso: instalaram-se também no vocabulário e na imaginação social dos cidadãos comuns (Moyn, 2010).

Entre os vetores de disseminação e normalização de políticas e discursos de direitos humanos estáo os mecanismos da chamada justiça de transição, um campo que combina reflexão e intervenção pública em ambientes marcados pelo legado de violências passadas, cometidas em contextos de guerra ou regimes autoritários. Consta que a expressão "justiça em tempos de transição" tenha sido usada pela primeira vez pela argentina Ruti Teitel, em 1992, para tratar dos modos de articulação entre direito e política em processos de estabilização institucional normalmente, em democracias recém-estabelecidas (Kritz, 2004). A mesma preocupação, como se sabe, já havia ganhado forma institucional nos Tribunais de Nuremberg (1945-1946) e Tokyo (19461948), mas apenas décadas depois inspirou reflexão e experimentação sistemáticas, sendo suas formas mais usuais os tribunais penais - com jurisdiçōes internacional e doméstica (Sikkink, 1995; Acuña e Przeworski, 1995) - e também as comissóes da verdade $^{1}$ (Hayner, 2011).

A despeito da variedade de mecanismos e circunstâncias de intervenção, teóricos e operadores da justiça de transição convergem em torno de uma expectativa comum: o esclarecimento de crimes passados é condição de sua não repetição e, portanto, de um novo tempo da política. Em geral, o dissenso entre eles tem a ver com o entendimento sobre a boa medida da justiça, isto é, com o que se compreende como um equilíbrio desejável entre custos políticos e ganhos morais das medidas transicionais. Pontuada pelo medo do retorno autori- tário, típico de jovens democracias, a literatura sobre justiça de transiçáo divide-se sobre o potencial disruptivo ou não das açóes de tribunal, orientadas por princípios duros de justiça retributiva, e sobre a capacidade ou náo de esses processos devolverem a dignidade roubada das vítimas.

Nesse contexto, as comissōes da verdade são concebidas tendo em vista dois enquadramentos principais. No primeiro, elas são admitidas e endossadas como parte de um processo que tem a justiça penal como telos (a exemplo de Orentlicher, 1991, e Sikkink, 1995). Alinham-se, nesses casos, com demandas vigorosas por punição. No segundo enquadramento, mais próximo a noções de justiça restaurativa, a busca por "verdade" é afirmada como finalidade em si (a exemplo de Tutu, 1999, e Boraine, 2008). Nessa perspectiva, a revelação pública de rotinas e operadores do passado violento já encarnariam uma forma de justiça. Em seu "guia para democratizadores", Samuel Hungtinton sugere um conjunto de interditos aproximado a essa premissa: "que não se processe, não se puna, não se perdoe e, acima de tudo, não se esqueça”. Para tanto, sugere a confecçáo de "um relatório público completo e desapaixonado de como e por que os crimes foram cometidos" (Huntington, 1994, p. 228). Trata-se de uma descrição próxima aos traços mais gerais dos documentos produzidos por comissóes da verdade. Escritos em "linguagem moderna", "sóbria, disciplinada" e orientada por uma vontade de "neutralidade", eles se aproximariam da forma típica "dos relatórios de direitos humanos", segundo Samuel Hopgood (2013, p. 74).

A produção de uma narrativa nesses moldes não se dá, claro, sem forte tensão com os rituais de comoção pública protagonizados por vítimas e familiares depoentes em sessóes de testemunho. Em contextos transicionais, comissóes da verdade tendem ao lugar de mediação entre partes que emergem de conflito político e carregam mágoas recíprocas. Se a paixão é permitida aos testemunhose as comissóes são o lugar institucional por excelência para as explosóes de emoçấo ${ }^{2}$-, tende a ser vedada aos comissionários. Deles se esperam modos conciliadores e moderados. A propósito, por exemplo, da primeira Comissão da Verdade uruguaia, Wilder Taylor ${ }^{3}$ observa o equívoco de ter se cons- 
tituído como "um exercício político, e não como uma empresa séria em busca dos direitos humanos" (Hayner, 2011, p. 241).

Em busca da etiqueta de seriedade, não foram poucas as comissóes da verdade que instruíram a investigação dos "dois lados" em conflito, como Serra Leoa, Libéria, El Salvador, Guatemala e a paradigmática África do Sul. Além de configurar os objetivos das comissóes, a vontade de imparcialidade comentada por Hopgood (2013) também ganhou forma em duas estratégias de composição de seus quadros. A primeira foi a de equilíbrio de antagonismos, baseado na composição plural do corpo de comissionários, com um largo espectro que vai potencialmente de representantes dos setores sociais mais atingidos pela repressão a membros de governo, parlamento, judiciário e até mesmo forças armadas. ${ }^{4}$ Nesse modelo, os sentidos de parcialidade são ou deveriam ser diluídos ou cancelados na abrangência e na diversidade dos seus membros. A segunda estratégia foi a de formação de comissóes com quadros híbridos, isto é, nacionais e estrangeiros (como no Haiti, na Guatemala, em Serra Leoa e na Libéria), ou mesmo exclusivamente não nacionais, com experiência em advocacia internacional de direitos humanos (a exemplo de El Salvador). Alheios e imunes às redes locais de política, poder e fidelidade, eles garantiriam a preservaçâo dos direitos humanos (Hayner, 2011).

No Brasil, a criação da Comissão Nacional da Verdade (CNV), em dezembro de 2011, não escapou à diretriz da imparcialidade ou do "desapaixonamento". O mesmo não se pode dizer, contudo, sobre as comissóes subnacionais da verdade. Mais próximas do ponto de vista das "vítimas", 5 elas se disseminaram no país após o lançamento da CNV, vinculadas a governos e legislativos estaduais e municipais por leis, decretos e resoluçóes. No domínio extraestatal, foram criadas por sindicatos, universidades e associaçóes profissionais.

A expansão ultrapassou, portanto, a iniciativa da $\mathrm{CNV}$, que, em seu relatório final, publicado em dezembro de 2014, sequer foi capaz de identificar o número exato de comissóes dedicadas à "busca da verdade", limitando-se a uma estimativa: elas somariam, naquela altura, cerca de cem em todo país. Tal dificuldade deveu-se à notável vitalidade do fenômeno, que contou com o lastro significativo de movimentos de familiares e militantes envolvidos, desde longa data, com as pautas de memória, verdade e justiça. ${ }^{6}$ Vigoroso entre os anos de 2012 e 2016, esse movimento de proliferação de comissóes da verdade que eu passo a designar comissionismo - teve seus andamento e diretrizes apenas em parte acompanhados pela CNV. Ela conviveu com estruturas semelhantes de menor porte, independentes e incentivadas por processos locais de sugestão-imitação, e se extinguiu antes que o ânimo expansivo arrefecesse. O repertório imaginativo de comissionários combinou referências metodológicas e modelares à $\mathrm{CNV}$ com horizontes mais palpáveis e imediatos das comissões de estados, municípios, universidades e sindicatos vizinhos.

Esses processos resultaram em um cenário bastante heterogêneo de comissóes da verdade. Neste artigo, atentarei a comissóes que articularam atores da "sociedade civil", conforme a fala de comissionários, e dos governos ou legislativos estaduais. A ênfase recai sobre a CNV e o conjunto das dez comissóes estaduais da verdade mais ativas durante o período da pesquisa, ${ }^{7}$ sediadas em Santa Catarina, Paraná, Rio Grande do Sul, Rio de Janeiro, São Paulo, Minas Gerais, Paraíba, Bahia, Pernambuco e Amapá. ${ }^{8}$ Para tanto, baseio-me na leitura sistemática de documentos oficiais, no acompanhamento de suas atividades em redes sociais e, principalmente, em entrevistas semiestruturadas com doze comissionários.

$\mathrm{O}$ artigo organiza-se em quatro seçóes. $\mathrm{Na}$ primeira, mais enxuta, apresento os principais personagens em questão, membros das comissôes da verdade, e trato também de apontamentos metodológicos sobre a condução da pesquisa. $\mathrm{Na}$ segunda, observo a inflexão do lugar do Brasil na cena da justiça de transição no mundo: da blanket amnesty aos direitos à verdade e à memória. Nas duas seçóes seguintes, passo ao objeto principal do artigo, isto é, o mapeamento de aproximaçôes e disjunçóes interpretativas e performativas entre as comissóes. Assemelhadas no objetivo mais geral de "busca da verdade", elas constituíram um ambiente polissêmico, atravessado por disputas - explícitas ou não - de versôes e sentidos para a experiência autoritária. A terceira seção detém-se nas premissas partilhadas 
entre as comissóes, isto é, a expectativa de pedagogia cívica e política da verdade (ou seja, a suposição de que a revelação do passado funda as condições para sua não repetição), a condição ahistórica das análises de violações de direitos humanos (que permite associaçóes bastante diretas entre violências passada e presente) e a suposta simbiose de sentidos entre democracia e direitos humanos.

Trata-se de uma espécie de chão comum que acolhe dissensos importantes. Eles são abordados na quarta e última seção deste artigo em dois eixos articulados e centrados no contraste de perfis entre os domínios nacional e estadual das comissóes. $\mathrm{O}$ primeiro eixo sugere que a proliferação das comissóes da verdade no país tenha sobretudo se baseado em um princípio avesso à "máxima da imparcialidade", acolhida pela CNV em linha com o receituário de praxe das comissões da verdade no mundo. Comissionários estaduais (e também municipais) tenderam a reivindicar legitimidade para suas ações, apresentando-se como mediadores da chamada "verdade das vítimas”. Os dois princípios em disputa aproximam-se, com modulações, de duas figuras de legitimação política identificadas por Pierre Rosanvallon (2009) na época contemporânea: "imparcialidade ativa" e "proximidade". No segundo eixo, o contraste diz respeito aos modos de compreensão da categoria "graves violaçóes de direitos humanos". A CNV aproxima-se da interpretação de praxe no direito internacional, centrada nos crimes de morte, desaparecimento, sequestro e ocultação de cadáver, destoando dela apenas para incluir casos de violência sexual e prisão ilegal, considerados correlatos aos primeiros. No nível estadual, as interpretaçóes da categoria de "graves violaçōes" foram mais maleáveis, acomodando as sensibilidades locais para a violência da ditadura, já que esta afetou de maneira distinta as diferentes regióes do país. Assim, localmente, os direitos humanos foram lidos em chave inovadora e a compreensão sobre a gravidade de suas violaçóes incluiu, por exemplo, os crimes econômicos e laborais, ao arrepio da praxe do direito internacional. ${ }^{9} \mathrm{Em}$ associação com o primeiro eixo de dissenso, as comissóes estaduais, ao se aproximarem do relato das vítimas sobre sua experiência, ultrapassaram os termos internacionais e genéricos da categoria de "graves violaçóes dos direitos humanos”, em geral definida, como se verá, em torno dos crimes de tortura, morte, desaparecimento forçado e ocultação de cadáver.

\section{Apontamentos sobre entrevistados e metodologia}

Antes de analisar o conteúdo das entrevistas e cotejar valores e perspectivas de ação, descreverei brevemente o perfil dos entrevistados. De saída, é fundamental dizer que o estatuto de personagem ou operador-chave que lhes atribuo não é devido a características que lhes sejam intrínsecas, mas ao lugar institucional que ocupam na cena das políticas de memória e verdade no Brasil. Embora as duas dimensões tenham imbricaçóes evidentes - uma vez que carisma e capacidade de liderança, por exemplo, são possivelmente atributos que conduziram militantes a lugares de destaque nas comissóes -, foi o segundo corte, institucional, que orientou a composição do corpo de entrevistados e também a escolha por omitir mençôes nominais a eles ao longo deste artigo. Não tenho em mente suas biografias ou pontos de vista particulares, mas sua condição de ator social.

Os entrevistados nesta pesquisa são presidentes ou figuras proeminentes da CNV e de dez comissóes estaduais da verdade no país. Fazem parte de um universo amplo e heterogêneo que chegou a somar quinze comissóes e cerca de 140 comissionários $^{10}$ (considerando-se apenas os níveis federal e estadual), e foi constituído conforme três parâmetros ${ }^{11}$ : (1) representação de setores da "sociedade civil" 12 e independência formal em relação a governos e quadros da política em geral, a exemplo de Amapá, Bahia (comissão do poder Executivo), Minas Gerais, Paraná e Rio Grande do Sul; (2) representação de câmaras legislativas, no caso de comissóes parlamentares, com diversidade formal de partidos, como em São Paulo, ${ }^{13}$ Bahia e Espírito Santo; (3) representação híbrida, isto é, de membros de legislativos, governos e sociedade civil, ${ }^{14}$ como Rio de Janeiro, Espírito Santo (comissão do poder Executivo), Goiás, Pará, Paraíba, Pernambuco e Santa Catarina.

Cada um desses segmentos reúne comissionários aos quais eu me referirei ao longo do artigo como "afetados" ou "não afetados" pela ditadu- 
ra. ${ }^{15}$ Além dessa clivagem, a heterogeneidade das comissóes é também resultado de seus diversos instrumentos de criaçãa $^{16}$ e escopos de ação, da sensibilidade profissional de seus membros ${ }^{17}$ e das diferentes histórias locais resultantes do confronto com a ditadura.

Distintas em suas designaçóes formais, nos quadros de comissionários e nos propósitos, as comissōes estabeleceram entre si articulaçōes frouxas, em geral associadas a relaçóes pessoais de afinidade e militância. Nesta pesquisa, que não propóe inferências estatísticas, mas apenas lógicas, causais e contextuais, busquei mapear e analisar a condição heterogênea das comissóes com base no depoimento de doze comissionários que me concederam entrevista. Interessada em observar variaçóes locais nas rotinas, nos desenhos e nas agendas de ação, consegui entrar em contato com membros de comissôes de quatro regióes do país. ${ }^{18}$ Mais do que opiniōes, crenças e valores pessoais, as entrevistas também revelaram escolhas e percursos institucionais que me permitiram estender diagnósticos e hipóteses explicativas que ultrapassam o círculo estreito de entrevistados. É assim que ao longo do artigo, por exemplo, as diferentes leituras apresentadas sobre os direitos humanos não são próprias apenas dos interlocutores diretos da pesquisa.

Em linha com o modelo que Mario Luis Small define como entrevista sequencial (Small, 2009), conduzi meu estudo de múltiplos casos com base em entrevistas semiestruturadas que me permitiram progressivamente uma melhor compreensão do objeto em pauta e um novo enquadramento das questôes. Os roteiros sofreram mutaçóes ao longo do período de entrevistas, de modo a incorporar nuances que antes me escapavam. Foi assim que cheguei ao ponto que Small define como saturação, com menos elementos que um survey me daria para a descrição da população de comissionários, mas possivelmente com mais recursos para compreender o universo das comissóes.

\section{Transição política e comissionismo no Brasil}

Em fevereiro de 2015, Kathryn Sikkink, professora e pesquisadora da Universidade de Harvard, publicou um artigo na Foreign Affairs em que propóe uma comparação qualitativa entre a CNV e outras 43 comissóes de verdade no mundo, estabelecidas desde 1972 (Sikkink e Marchesi, 2015). Para tanto, mobiliza a base de dados do Transitional Justice Research Collaborative ${ }^{19}$ e apresenta conclusóes muito favoráveis à CNV: em escala qualitativa de zero a sete, a CNV recebeu nota seis. ${ }^{20}$ Para Sikkink, a experiência da CNV marcaria uma clara linha de distinção entre o tempo passado, do "esquecimento" ensejado pela Lei de Anistia de 1979, e o tempo presente, afinado com o objetivo de publicidade sobre a violência da ditadura. ${ }^{21}$ Apesar do sentido virtuoso dessa trajetória, ela seria ainda insuficiente. A expectativa de Sikkink, e de quase todos os comissionários entrevistados aqui, é de que os ganhos de "verdade" sirvam de instrução para processos judiciais. Incapaz de garantir o passo decisivo em direção à punição de criminosos do passado, uma espécie de telos das sociedades transicionais, a CNV inspira apenas um elogio de meios e compóe a expectativa de um processo cujo corolário é projetado em um futuro que se espera próximo.

O princípio da anistia constitui, nessa perspectiva, uma espécie de ausência fundante da nova democracia. Na memória sobre a transição nacional, a caracterização das faltas ganha contornos nítidos na comparação com a experiência modelar dos tribunais argentinos, que encarnariam um sentido inequívoco de ruptura com o regime extinto. É lugar comum na fala de comissionários brasileiros o contraponto entre o vigor e a agilidade argentinos - por vezes projetados na América Latina em geral - e a letargia política nacional. ${ }^{22} \mathrm{O}$ Brasil seguiu por décadas alheio à novidade latino-americana das comissóes da verdade, fiel ao arranjo político que constitui uma espécie de mácula de origem da sua democracia. Aos termos irresolutos do Estado se somaria uma sociedade resignada à democracia sem solavancos.

Se a narrativa de imobilismo social e político é tomada como verdadeira, o observador da cena contemporânea teria poucas pistas para compreender o fenômeno do comissionismo e poderia tender a uma descrição em chave espontaneísta, concebendo-o como uma súbita e generalizada tomada de consciência, sem atenção aos acúmulos históricos que compóem as suas bases. Nas falas de comissio- 
nários, contudo, as representaçôes sobre os grupos de militância dedicados a pautas da ditadura contrastam fortemente com a chave da letargia cívica atribuída à população em geral. A luta de familiares de desaparecidos e ex-perseguidos políticos, objeto de alusóes reiteradas, teria desaguado no presente engajado das comissóes. Tal como descritas pelos comissionários, elas seriam a encarnação de virtualidades contidas na história, resultado de acúmulos paulatinos e passíveis de antecipação e compreensão pelo exame do passado.

Entre esses extremos, que suspendem ou afirmam exageradamente a história e o passado como elementos explicativos do presente, observo no comissionismo tanto elementos de continuação ou afinidade com atores e lutas históricas, quanto um forte presentismo contido no efeito-contágio de umas comissóes sobre as outras. Nessa dinâmica mimética, em que grupos de políticos e/ou ativistas copiam ou se aproximam fortemente de modelos inaugurados por outros grupos, as comissôes com maior capacidade de organização e articulação política não são necessariamente tomadas como arquétipo. Se é certo que comissóes de maior porte serviram de exemplo a comissionários em geral, é fato que os espelhos locais serviram por vezes como maior fonte de inspiração, - a exemplo da comissão do Pará, muito próxima ao modelo do Amapá e criada em estreita colaboração com ela. Se há uma dimensão difusa de contágio centrada num certo espirito comissionista ${ }^{23}-\mathrm{e}$, nesse sentido, o protagonismo da CNV e das comissóes estaduais mais expressivas, como de São Paulo, Pernambuco e Rio de Janeiro, é inescapável -, a mimesis institucional em um nível mais operacional tende a se concentrar nos eixos locais.

Apesar das novidades, o comissionismo não configurou, conforme supóe Sikkink em relação à CNV, uma inflexão do "esquecimento" à "verdade". $\mathrm{Na}$ linha temporal que se estende entre o período da redemocratização e a atualidade, o que se observa são diferentes modulaçóes do princípio reparador articulado pelo Estado. Segundo Paulo Abraão e Marcelo Torelly (2011), o Brasil seguiu seus próprios caminhos transicionais - discrepantes de experiências e manuais internacionais - e sua agenda oficial de memória e verdade foi grosso modo um desdobramento da própria Lei de Anistia, que já anunciava a necessidade de reparação laboral aos afetados pela ditadura. A consolidação democrática converteu o princípio vago em programa vigoroso, com alocação de cerca de 8 bilhões de reais em indenizaçóes, ${ }^{24}$ um dos fundos mais robustos de indenização no mundo depois dos programas de reparação a vítimas do nazismo. Essa máquina indenizadora foi operada pela Comissão de Mortos e Desaparecidos e, sobretudo, pela Comissão de Anistia, investidas de poderes e instrumentos de investigação, mas sobretudo alimentadas por provas materiais e testemunhais recolhidas pelos próprios pleiteantes.

A CNV deu um passo decisivo no tratamento das agendas de memória e verdade como questôes de interesse público: ela descolou a verdade do propósito de reparação financeira e postulou-a como objetivo em si, de responsabilidade do Estado (e não de suas vítimas). A novidade foi dirigir seu esforço investigativo, incrementado pela Lei de Acesso à Informação, para esclarecer estruturas e redes da repressão, e, desse modo, investigar e compreender casos individuais de vitimação com referência ao quadro mais geral de violaçóes do regime. Em termos formais, essa inflexão relevante não colidiu com as diretrizes de 1979: sua lei de criação mobilizou princípios de direitos humanos e reconciliação perfeitamente acomodados aos termos da anistia. $\mathrm{Na}$ prática, contudo, a CNV e o comissionismo tensionaram - com diferentes formas e intensidades - os discursos de reconciliação e anistia. Além de ocupar sessóes públicas e relatórios parciais e finais das comissões, ${ }^{25}$ a denúncia da anistia - e do paradigma da reconciliação sobre o qual repousa também tomou de improviso o debate público.

\section{Do chão comum ou da intersubjetividade dos comissionários}

As fronteiras elásticas dos direitos humanos variam ao sabor das percepçóes de carência. O repertório em movimento dos direitos humanos engloba, portanto, as disputas de interpretação sobre o mundo, mas os dissensos entre seus operadores não escapam a uma espécie de intersubjetividade do campo. Abordarei essa questáo observando três 
ideais reguladores, que são também ângulos de descrição do mundo, partilhados por todos os comissionários que compóem o corpo de entrevistas deste artigo. O primeiro denomino "pedagogia da verdade", seja ela flexionada em formas jurídica, histórica ou memorialista; o segundo diz respeito ao que seria uma condição atemporal ou ahistórica dos direitos humanos e suas violaçóes; o terceiro tem a ver com a aproximação ou mesmo a simbiose de sentidos entre democracia e direitos humanos.

A premissa de pedagogia da verdade compreende um ritual enunciativo ou, simplesmente, um ato de desvelamento de eventos ou rotinas de violência que antes não se davam a conhecer publicamente. Estabelecida a "verdade", supóe-se - ou quer-se supor - que estejam dadas as condiçóes para superar a repetiçáo de vícios passados. Estanca-se a espiral de violaçôes de direitos humanos, como se a verdade tivesse efeito "profilático", conforme expressão usada por um comissionário da Bahia. É notável, entre os entrevistados, a premissa de homologia entre saber e evitação do mal. ${ }^{26}$ A premissa de um laço de causalidade entre a "verdade", em versôes memorialística ou judicial, e o "nunca mais" tornou-se uma espécie de lugar comum entre operadores de comissôes da verdade e tribunais.

$\mathrm{Na}$ fala de comissionários, "verdade" não se opóe a mentira, mas a "esquecimento" - um fenômeno investido de forte sentido de agência do Estado, e não uma mera consequência do tempo transcorrido. Faz-se esquecer, portanto; não se esquece simplesmente. Segundo uma comissionária do Rio de Janeiro, trata-se de uma "estratégia nefasta e perversa" que se lança sobre o terreno fértil de uma sociedade alheia ao problema das violaçóes de direitos humanos. Outros comissionários convergem na percepção de um a priori social arredio à democracia, expresso nas noçôes de "cultura autoritária", "cultura antirrepublicana” e "cultura política precária”, segundo comissionários do Amapá, de São Paulo e de Minas Gerais, respectivamente. Para a entrevistada mineira, na mesma linha, "a sociedade que surge de uma coisa escravocrata é muito difícil”.

O tema da continuação ou mesmo da indistinção social e política entre passado e presente é uma espécie de ponto de partida comum aos comissionários. E aqui passo a tratar do que defini como a segunda premissa comum aos operadores de memória e verdade: a indistinção ou a suspensão analítica das variaçôes de tempo e circunstância. Em outras palavras, a condição ahistórica dos direitos humanos.

No repertório discursivo dos entrevistados, passado, presente e futuro são linhas entremeadas, inapreensíveis de maneira isolada. Apesar da variedade de leis e instrumentos legais que definem seu escopo de ação, os mandatos das diferentes comissóes são todos referidos ao esclarecimento sobre eventos da ditadura. A despeito disso, as comissões aludem continuamente à denúncia de violências em curso, o que só é possível em combinação com uma concepção do passado como tempo aberto ou inacabado, que prolonga seus vícios no presente e potencialmente no futuro.

No mundo heterogêneo de comissóes e comissionários, um diagnóstico e uma repulsa comuns atravessam seus discursos: a novidade formal da democracia não resolveu o problema das violaçóes de direitos humanos por agentes de força do Estado. $\mathrm{Na}$ fala do comissionário de São Paulo, essa denúncia-lamento ganha forma explícita:

Como é que você explica que as forças armadas, em período da democracia, estejam no Complexo do Alemão? Todas as UPPs [Unidades de Polícia Pacificadora] foram criadas a partir de conceitos militares: zonas de guerra e inimigos. São zonas totalmente militares, quaisquer assassinatos que ocorram e não sejam previsíveis de julgamento é resistência seguida de morte. É a mesma terminologia.

Para o entrevistado da CNV, "o fato de que a tortura ficou impune faz com que hoje se torture no Brasil. É direta essa correlação". O mesmo diagnóstico motiva o espanto da comissionária do Rio de Janeiro: como é possível "as pessoas" não associarem "a polícia que mata dentro de uma unidade da UPP com uma polícia que matava dentro de um DOI/CODI"? Comissionários operam uma permanente e reiterada vinculação entre "o que foi" e "o que é". ${ }^{27}$ Nesta narrativa de longa duração, há um chão comum entre Amarildo ${ }^{28}$ e Rubens Paiva: faltaram, a um e a outro, democracia e respeito aos direitos humanos. 
E aqui passo ao terceiro e último tópico desta seção: a premissa de complementaridade entre direitos humanos e democracia. No léxico dos comissionários, as duas noçóes se implicam reciprocamente, sendo a boa democracia condição dos direitos humanos e os direitos humanos, condição da boa democracia. Esse entendimento compreende um lamento pela democracia de fato, violadora de direitos, e também o desejo por uma certa democracia, comprometida com eles.

Aqui e ali, contudo, a convicção normativa choca-se com a observaçáo dos "fatos" do mundo. Quando o curso da entrevista conduz os entrevistados ao tema das manifestaçóes sociais recentes em favor de caminhos autoritários para a política, o elo perfeito entre democracia e direitos humanos parece se romper. $\mathrm{O}$ que fazer, afinal, quando a democracia se volta contra os direitos humanos? $\mathrm{Ou}$, mais precisamente, quando os direitos humanos são questionados por cidadãos no gozo de suas liberdades democráticas? A fala dos comissionários assume um tom de perturbação:

A nós brasileiros foi roubada uma coisa muito importante que se chama democracia, que se chama, se chamava e deve-se continuar chamando democracia. As pessoas hoje vão para a rua pedindo a volta dos militares. $\mathrm{O}$ significa o que isso? [Comissionária de Minas Gerais].

São manifestações públicas, de defesa da ditadura e retorno do golpe militar e de certa forma de banalização da violência, contra a dignidade da pessoa humana. Isso é estarrecedor. [...] Será que é um problema de descrédito da democracia? [Comissionário de Pernambuco].

A resposta ao desalento reitera e aprofunda o programa de imunização da sociedade empreendido pelas comissóes. E aqui o argumento ganha circularidade: retornamos ao tema da "profilaxia" da verdade. Para o entrevistado do Amapá, a "onda conservadora se sustenta na ignorância sobre o que ocorreu na ditadura, uma ignorância absoluta mesmo". Se a democracia dá sinais de colidir com os direitos humanos, é porque não foi suficientemente instruída. $\mathrm{Na}$ ausência da "verdade", conforme o comissionário de São Paulo, o "autoritarismo arraigado na cultura brasileira”, em estado latente, ressurge. As expressóes de ceticismo, aliadas a uma sensação de prostração, não chegam a esvaziar o discurso da ação. Não havendo alternativa, persiste-se na busca de "verdade"; aumenta-se a dose do remédio. Os caminhos para isso, contudo, estão abertos à disputa, como se verá na próxima seção.

\section{Dos diferentes direitos humanos}

Depois de apresentar as convergências entre as comissóes, passo agora a tratar dos conflitos de perspectiva explícitos e articulados em discurso ou apenas entrevistos nas suas ações. $\mathrm{Na}$ investigação das dissonâncias em relação à compreensão dos direitos humanos e às formas de alcançá-los, organizarei meu argumento em duas partes. A primeira trata da composição dos quadros das comissóes; a segunda aborda as divergências sobre a metodologia de trabalho e sobre a categoria "graves violaçôes de direitos humanos".

\section{Composição de quadros das comissóes da verdade}

A composição de quadros é o único tópico que antecede a instalação de uma comissão, tarefa empreendida por legisladores e governantes que podem ou não se tornar seus partícipes. Os perfis dos comissionários organizam-se em torno de dois eixos de legitimidade presumida, ligados ora ao princípio de "imparcialidade ativa", ora ao de "proximidade”, que Rosanvallon (2009) supóe serem duas figuras-chave de legitimidade da democracia na cena contemporânea. No cenário amplo e heterogêneo das comissóes, os dois eixos são reivindicados em discurso ou simplesmente experimentados, com variações que vão de rígidas marcações de distinção a fórmulas híbridas sem tensóes pronuciadas. $\mathrm{O}$ comissionismo incluiu, portanto, diferentes combinações e modulações locais dos dois princípios.

A lei de criação da CNV (n. 12.528, de 18 de novembro de 2011) definiu que seus membros fossem pessoas de "reconhecida idoneidade e conduta ética, identificados com a defesa da democracia e $\mathrm{da}$ institucionalidade constitucional, bem como 
com o respeito aos direitos humanos". No mesmo artigo, lê-se ainda que é vedada a participação daqueles que "não tenham condiçóes de atuar com imparcialidade no exercício das competências da Comissão". Na prática, além da exclusão de militares e figuras associadas ao exercício ou aos valores políticos da ditadura, a interpretação dessa cláusula significou a composição de um corpo de comissionários não diretamente afetados pelo regime, isto é, pessoas que, reputadas pelo compromisso com a democracia e os direitos humanos, não tivessem sido presas, torturadas, constrangidas a esconder-se ou exilar-se em decorrência da ação persecutória da ditadura. A premissa de fundo era de que a afetação direta de comissionários pelo regime poderia comprometer a isenção de seus trabalhos.

O discurso de Dilma Rousseff na instalação da CNV endossou essa preocupação com o arranjo delicado a ser instaurado: "escolhi um grupo de cidadãos e cidadãs de reconhecida competência, sensatos e ponderados, preocupados com a justiça e o equilíbrio". ${ }^{29} \mathrm{O}$ perfil imputado aos comissionários tem afinidade com a atitude de "imparcialidade ativa", atribuída por Rosanvallon a sujeitos avessos a pré-julgamentos, mas situados no mundo de paixóes, conflitos e, portanto, parcialidades. Para os legisladores da CNV, trata-se de uma disposição inacessível a pessoas cujas biografias as tornem reféns de "revanchismo" e "acerto de contas", conforme expressôes de Rousseff, que compóem a noção de "posições fechadas" de Rosanvallon (2009, p. 162). Supunha-se que o interdito à inclusão de comissionários implicados pessoalmente nos assuntos da CNV garantiria a independência de seu corpo dirigente em relação às matérias sob investigação, o que seria compatível com um ideal de compromisso sem afeto desmedido, com modos racionais e moderados.

O tema da objetividade ou do "desapaixonamento", para recuperar a formulação de Huntington, extrapolou o momento de formação da CNV, passando a compor seu repertório de justificação e autodescrição. Conforme seu último presidente, a CNV teria como objetivo primordial a busca pela "verdade factual", pouco suscetível a discordâncias. Diferentemente da especulação sobre causas da violência, que faz eclodir um sem número de narrativas sobre o mesmo evento, a "simples descrição" dos fa- tos é "mais forte", "fala por si só". No lugar da noção de "verdade histórica", que "envolve a construção de uma narrativa explicativa", optou-se pela "crueza dos fatos". Todos os comissionários teriam convergido, segundo ele, em torno desta afirmação: "nós não temos que ter opiniāo sobre as coisas, nós temos é que apresentar os fatos". O resultado disso seria um "relatório de músculo e osso, sem gordura”.

Em franca colisão com essa perspectiva, foi concebida a Comissão da Verdade da Assembleia Legislativa do Estado de São Paulo "Rubens Paiva". Os termos de sua criação opuseram-se frontalmente àqueles da $\mathrm{CNV}$, segundo o comissionário de São Paulo:

Você sabe por que a comissão da gente chamava Rubens Paiva? Claro, ele é um personagem paulista maravilhoso, deputado, mas, além do clichê, a Vera [filha de Rubens Paiva] foi pra Brasília [na sessão de instalação da CNV] com um pronunciamento preparado para falar do pai, mas não pôde ler o texto por uma saia justa com os militares. Mas aí ela voltou pra São Paulo e leu o texto aqui na Comissão de São Paulo e o nome do Paiva é um confronto a isso [grifo meu].

Proposta por instrumento legislativo como comissão parlamentar, a Comissão Rubens Paiva (CRP) foi instaurada pelo comissionário em questáo, ${ }^{30}$ um deputado cuja figura pública é associada à resistência à ditadura, tendo sido ele próprio preso e torturado pelo regime. Embora tenha atendido às exigências formais de comissóes parlamentares, com representação formal de diversos partidos políticos, o deputado-comissionário refere-se à comissão paulista como uma "comissão de esquerda, uma comissão militante". Para tanto, contou com assessores que se tornaram sua principal face pública: militantes historicamente envolvidos com a pauta dos crimes da ditadura, vitimados pela ação violenta do regime. Seu ponto de partida invertia o da CNV: sáo justamente os afetados pelo regime, há décadas envolvidos com a busca de informaçóes sobre crimes passados, que teriam maiores possibilidades de produzir uma narrativa sistemática sobre a atuação da ditadura. 
Ao suspender o interdito do enlaçamento de comissionários com o objeto da comissão, ele se aproximou de outra figura de legitimação democrática: "proximidade" (Rosanvallon, 2009). Em evidência desde o final dos anos de 1990 como uma nova face da expectativa sobre o bem político, o autor argumenta que seus adeptos seriam refratários a exercícios automáticos da regra, insensíveis às circunstâncias particulares da vida. Mais do que o benefício próprio no resultado da interação com setores públicos, os cidadãos esperariam - e valorizariam sobretudo - a consideração de sua situação específica. Experiências de "proximidade" recorporificavam o político e atuavam no sentido de aplacar os sentimentos de "abandono", "esquecimento, indiferença e desprezo" (2009, p. 274). Nos termos do comissionário paulista, valorizavam a "vivência pessoal" de cada um.

$\mathrm{Na}$ sua fala, a CNV constitui uma espécie de antimodelo de ação: "enquanto na Nacional [CNV] não podia ter família envolvida, militante, aqui tinha tudo isso". Para o deputado-comissionário, "toda vez que o Estado, o governo, a estrutura oficial entra na questão da ditadura, entra pela porta dos fundos, faz uma enorme confusão"; ao invés de "entrar pelo lado da naturalidade, dos familiares das vítimas, dos atingidos, quer entrar pela superestrutura. Isso está errado" [grifo meu]. O argumento da naturalidade é articulado contra a expertise como condição suficiente da ação política: haveria ali, nos postos de comissionários, "grandes advogados, juristas... pessoas maravilhosas, mas que não entendem nada de ditadura". ${ }^{31} \mathrm{E}$ prossegue: "esse jeito franskstein da comissão foi um desespero." Investidos de uma relação apenas intelectual com a ditadura, faltava aos comissionários da CNV a autoridade da experiência vivida.

Apesar do contraponto estrito sugerido pelo comissionário paulista, a apropriação dos princípios de imparcialidade, de um lado, e proximidade, de outro, náo se deu de modo absoluto, como tipos puros. Na composição dos grupos de trabalho, por exemplo, a CNV valeu-se do princípio de proximidade para a criação do grupo denominado Trabalhadores, conduzido por figuras sabidamente afetadas pela violência do regime militar. A CRP, por sua vez, cercou-se de um corpo técnico jovem e não afetado pelo regime.
No quadro mais amplo do comissionismo, a proliferação da perspectiva "militante", em alusão a uma categoria nativa bastante usual entre comissionários, foi mais suave do que o modo como ocorreu na CRP, com a composição, na sua grande maioria, de quadros combinando "afetados" e "não afetados" diretamente pela ditadura. Seis das dez comissóes estaduais em investigação tiveram composição híbrida. Apenas a comissão de Minas Gerais foi composta unicamente por pessoas que foram atingidas de modo direto pela repressão política, mas não fez disso uma questão de princípio. As comissóes do Acre, do Paraná e do Rio Grande do Sul não tiveram comissionários afetados diretamente pela ditadura, e isso tampouco foi considerado uma questão identitária forte.

\section{Metodologias e objetivos das comissóes da verdade}

Além do viés "militante", as comissóes estaduais também se distinguiram da CNV por inflexões metodológicas e objetivos distintos, os quais organizam o segundo eixo desta seção. Para o deputado-comissionário de São Paulo, "no mundo inteiro, as vítimas, os depoentes e o testemunhal têm um valor fantástico". Em desalinho com essa tendência, a CNV teria uma "coisa secreta" em suas rotinas. Ele se referia à condução de depoimentos a "portas fechadas". Em grande medida - e mais uma vez São Paulo é a comissão que leva o dissenso ao limite -, os depoimentos foram concebidos como rituais de comoção e sensibilização pública sobre a violência da ditadura (e também sobre a violência contemporânea em geral).

Em franco contraste com a CNV, que promoveu 246 depoimentos públicos ao longo de seu mandato, a Comissão Rubens Paiva conduziu 941. Em relação a outros estados, a disparidade é menor, mas, ainda assim, expressiva, sobretudo quando se considera sua estrutura consideravelmente reduzida em relação à $\mathrm{CNV} .^{32}$

Ao sigilo dos testemunhos somou-se, de acordo com o deputado-comissionário paulista, a denúncia do que seria um regime de restrição da CNV: ela "não podia mexer com militar, Itamaraty, operação Condor...”. Mais uma vez, o entrevistado define a CRP pela negação: "aqui [em São Paulo] a gente fez 
tudo que eles náo fizeram, não tínhamos detector de metais". Uma postura semelhante é identificada pelo comissionário pernambucano: contra a "teoria dos dois demônios" e em torno da pauta de "mortos e desaparecidos" pelo regime, as comissóes em geral assumiram uma "atitude de enfrentamento" mais explícita com militares. A volumosa seção sobre "mortos e desaparecidos" no relatório final da CNV teria resultado da força dessa demanda. $\mathrm{Na}$ fala do comisionário da CNV, trata-se da "pauta de familiares".

A aproximaçáo das comissóes com a experiência dos "afetados" pela ditadura é também um marcador importante do terceiro eixo de dissenso, relativo às "graves violaçóes de direitos humanos". De saída, é importante ter em mente que, embora essa seja uma categoria-chave de organizaçóes e tratados internacionais de direitos humanos, ela carece de uma referência normativa precisa (Astolfi e Lagatta, 2015). Costuma designar os crimes de tortura, morte, desaparecimento forçado e ocultaçáo de cadáver. No Brasil, a lei de criação da CNV acompanhou a praxe internacional. A prática da comissão, contudo, ampliou seu escopo para acolher casos de violência sexual e prisões ilegais, consideradas, segundo seu comissionário, "porta de entrada" dos crimes tipificados. O ajuste na tradução de normas em práticas não feriu a intenção mais geral do legislador, explica o comissionário entrevistado: "uma série de coisas" ficaram de fora pois "fugiam a seu escopo". Diante do repertório extenso de violação de direitos promovido pela ditadura e também das limitaçôes práticas de uma comissão da verdade, a $\mathrm{CNV}$ teria, segundo ele, produzido uma "escolha metodológica correta".

As comissóes estaduais, por sua vez, tenderam a leituras mais largas a respeito da definição do conceito de "graves violaçóes", embora seus instrumentos de criação as considerassem colaboradoras da $\mathrm{CNV}$ e, portanto, potenciais continuadoras de suas tipologias de trabalho. Calcadas na observação das formas locais de repressáo do regime, aproximaram o tema da gravidade às suas realidades. Ao propor novas aplicaçóes, os comissionários lançaram-se a uma disputa de narrativas sobre o regime. Aqui penso em atores de estados periféricos, em geral alijados do imaginário sobre a repressão. O comissionário da Paraíba, por exemplo, tem clareza sobre o objetivo da sua comissáo de chamar atençáo para o que aconteceu ali:

Temos uma produção historiográfica muito forte da experiência do Brasil, mas com pouca visibilidade dos atores que atuavam nos espaços menores do país. A importância das comissôes estaduais é dar visibilidade a esses atores que sofreram violaçôes de direitos humanos ou sofrearam repressão da ditadura e que tiveram pouca visibilidade. [...] quando eu pego algum arquivo sobre a Paraíba, eu sempre falo que o objetivo não é fazer história estadual, já que se fosse no Sudeste seria história do Brasil.

$\mathrm{Na}$ fala de outros comissionários, o acento recai sobre a negligência do tema da ditadura por parte dos próprios cidadáos locais. $\mathrm{O}$ comissionário do Amapá, por exemplo, é muito direto a esse respeito: "tem uma polêmica muito grande no meio da intelectualidade local sobre se houve ou não houve ditadura no estado do Amapá". No Paraná, o entrevistado ressente-se do que seria um "relato comum da sociedade paranaense" e também "um discurso oficial na grande imprensa", minimizadores da ditadura. Caberia à comissão desconstruir essa "falsa história". No lugar do estudante subversivo envolvido com organizaçóes de luta armada nos grandes centros urbanos, as comissōes do Paraná, de Santa Catarina, da Bahia, da Paraíba e do Amapá trouxeram "novos" personagens - populaçóes indígenas, camponeses, políticos cassados e "trabalhadores" 33 para esse cenário, que correspondem justamente às novas interpretaçóes a respeito do que deve ser considerado "graves violaçóes de direitos humanos".

A questão indígena foi mais enfatizada na comissão do Amapá, ${ }^{34}$ empenhada em descrever os crimes econômicos ${ }^{35}$ cometidos pelo regime militar que vitimaram populaçôes não engajadas no questionamento do regime e, por isso, marginais aos esforços investigativos da CNV. ${ }^{36}$ Se a escassez ou a indisponibilidade de provas da repressão é um problema que atinge as comissóes da verdade em geral, no caso da comissão do Amapá, atenta às populaçôes indígenas, a desinformação é extrema. Por fugirem à tipologia de criminoso político, é difícil conhecer como índios foram atingidos pelo regime militar. O comissionário do Amapá lamenta: 
[...] a gente tem uma dificuldade muito grande de conseguir a comprovação histórica do que ocorreu com eles [os índios]. Eu vou te dar um exemplo: durante a ditadura, de meados dos anos 60 até o final de 1975, foi construída a BR 156, que corta o Amapá de norte a sul. E até hoje o Amapá é um estado onde tem uma das maiores populaçóes indígenas. Imagine na época.

Soma-se à escassez de lastros materiais do "sofrimento imposto aos indígenas" a dificuldade de lidar com suas "narrativas mitológicas" em um ritual estruturado para contemplar o testemunho individual regido pelo princípio da história linear. Embora, de fato, sejam avessos à linearidade e vulneráveis às desordens da memória e da emoção, os testemunhos evocam marcaçóes temporais que permitem ao historiador compor narrativas como mosaicos. A forma mitológica exigiria uma outra sensibilidade compreensiva, arredia a repertórios cognitivos tipicamente ocidentais.

A condição dos camponeses aproxima-se da invisibilidade dos indígenas, mas não se confunde com ela, porque foram personagens que "atuaram politicamente contra a ditadura". Atenta aos modos de repressão no campo, que fundiram Estado e "milícias privadas" em ações de cooperação ou simples conivência, a comissão da Paraíba teve como objetivo "visitar comunidades rurais e recuperar a memória de pessoas anônimas". Diante dos "vários tipos de violaçôes" da ditadura, a comissão não poderia "se deter só naquelas violaçóes de tortura”. Seria necessário ampliar o foco para tratar de "pessoas que tiveram enfrentamento com a ditadura", que "resistiram de alguma forma" a ela, mas que não "são vistos, não são citados". O comissionário defendeu a recuperação de "falas e memórias sobre o período" e propôs que "isso seja considerado táo nacional quanto o que é produzido na região Sudeste, sobretudo no Rio de Janeiro e em São Paulo”.

Por fim, a categoria "graves violações de direitos humanos" é ainda expandida para abarcar as políticas demissionárias articuladas por governos e setor privado com o propósito de impedir a inserção laboral de pessoas consideradas subversivas, postulando o status de gravidade para as demissóes: "Quanta gente perdeu emprego porque era subver- sivo? Quanta gente passou fome porque não tinha como ganhar dinheiro? Quantas famílias foram desagregadas por isso?” No Rio Grande do Sul, reflexôes semelhantes mobilizaram o comissionário:

[...] cheguei à conclusão que cassação é grave mesmo. Uma senhora disse que a pior tortura quando saiu do DOPs foi não conseguir trabalhar. Tivemos aqui um Coronel que fugiu. [...] Ele era aviador militar e poderia, por lei, exercer aviação civil. Mas não podia trabalhar. Havia uma portaria secreta que o impedia. Nas camadas populares náo precisava dessas portarias. Passavam listas para sindicatos.

No âmbito dos estados, outros perfis profissionais foram somados às listas. No Amapá, por exemplo, onde o "Estado era tudo", isto é, onde "a administração pública" abarcava "grande parte da sociedade" local, os trabalhadores eram servidores que foram atingidos pela "chamada comissão de investigação sumária", criada pelo "governo da época" e "composta por três membros que tinham o poder de exonerar”. Sua ação não era necessariamente dirigida a militantes notórios, a exemplo do prefeito de Macapá, que "não tinha nenhuma formação super sólida de resistência socialista nem nada. Era simplesmente uma pessoa de espírito mais democrático que se revoltou com algum tipo de... e aí foi sumariamente cassado". Na Paraíba, segundo o comissionário, embora os agentes da repressão tenham se concentrado na perseguição às ligas camponesas, extrapolaram seu alvo imediato, atingindo também o "campo político". As cassações de mandatos de vereadores, prefeitos e deputados, além das demissóes de juízes, todas foram justificadas por terem tido "algum tipo de vinculação com as ligas camponesas".

As novas narrativas sobre a ditadura não foram exclusivas das comissóes estaduais, mas a ênfase e o protagonismo conferido a elas lhes são próprios e distintivos. $\mathrm{O}$ contraponto entre nacional e local não é rígido ou estrito e admite zonas de interseção. Assim, os três eixos de expansão da categoria "graves violaçôes de direitos humanos" nas comissóes estaduais periféricas também compóem o relatório final da CNV, ainda que ocupem ali um lugar de pouco 
destaque, como se fosse uma verdade menor ou, ao menos, não oficial. Segundo o comissário nacional, os "temas novos", de "vanguarda", alcançaram apenas um grau "incipiente" de verificação e articulação, distinto do "rigor de investigação" imposto aos outros temas. Concentraram-se no volume 2 do relatório, em que figuram "textos autorais, de grupos ou de membros da comissão", os quais se dedicaram a eles "em caráter quase pessoal algumas vezes". Embora a "relevância" desses temas tenha sido reconhecida, a CNV não avalizou todas as passagens expostas no texto, tanto que os volumes 1 e 3 receberam o endosso da comissão como um todo e o segundo foi assinado individualmente pelos autores. Do relatório da CNV resultaram, portanto, diferentes status de verdade. Ao fazer isso, a CNV não enfrentou, como observa San Romanelli (2015), a pauta da colaboração entre o regime e os setores privados - categoria ampla que engloba desde a ação de grupos de extermínio e capangas de latifundiários até empresas nacionais e multinacionais. Nas comissóes estaduais, os operadores deslocaram os temas marginais da CNV para sua agenda principal, recompondo a categoria "graves violaçōes de direitos humanos" e conduzindo o entendimento da "verdade" sobre a ditadura por caminhos vários.

\section{Notas finais}

"Como pode ser que alguns estados ainda não tenham suas comissóes da verdade?", indagou-me um dos entrevistados em tom de denúncia-lamento, embalado no diagnóstico de uma sociedade com lastros autoritários. Recebi sua indignação com surpresa, pois o que vinha me intrigando desde o início da pesquisa era justamente uma questão contrária, isto é: como podia ser que tantos estados (e municípios, sindicatos e universidades) tivessem instalado comissóes da verdade em um espaço tão curto de tempo? Entre os militantes, a novidade radical - nunca experimentada em nenhum outro lugar do mundo - deu lugar a um horizonte de expectativas normalizado. Para o entrevistado, e possivelmente também para os atores no seu entorno, o desafio passara a ser compreender a ausência, e não a presença de comissões.
Neste artigo, detive-me mais nos caminhos que nas origens do fenômeno. Arrisco-me, contudo, a tratar de um e outro com base em um diagnóstico comum: a imbricação do governo (em diferentes níveis) e de movimentos sociais vinculados à pauta de "memória, verdade e justiça" em uma articulação estreita e recíproca. A condiçâo híbrida do comissionismo é inescapável. Ela invalida, de um lado, narrativas de um formalismo incipiente - tipicamente associadas a iniciativas de governo que não encontram eco nos domínios sociais que tomam por objeto - e, de outro, ideias românticas de insurgência espontânea de movimentos sociais, independentemente dos espaços e dos atores formais da política. A proliferação de comissóes da verdade no país combinou iniciativas, mecanismos e acúmulos políticos de um e outro - governo e sociedade civil.

Desde 2012 e ainda presente atualmente (embora em processo de extinção), o comissionismo passou por uma renovação de mandatos políticos que fez emaranhar, ainda mais, as duas dimensôes em questão. Seus quadros são móveis, sujeitos à circulação de atores entre movimentos sociais e cargos políticos. Não foram poucos os que, em 2014, por exemplo, migraram de mandatos como deputados ou vereadores para a representação de segmentos da sociedade civil em comissóes da verdade e, na mão inversa, de representaçóes de sociedade civil em comissóes da verdade que passaram a cargos eletivos em âmbitos diversos. A condição híbrida, como tratei ao longo deste artigo, refere-se ainda à ação concertada entre "afetados" e "não afetados" pela ditadura. As comissóes estaduais foram movidas por essa teia de personagens com diferentes perfis institucionais, biográficos e geracionais e tenderam a suspender os interditos de vinculação entre motivaçóes pessoais (em decorrência de vitimação) e ações de governo.

Justamente aqui - entre outros aspectos - os operadores locais do comissionismo inovaram em relação ao campo político e intelectual da "justiça de transição" no mundo. A inflexão no sentido de maior pessoalidade dos processos - sem prejuízo do argumento forte de interesse público do seu objeto também repercutiu no desenho de suas pautas, mais próximas das realidades locais. As comissões estaduais produziram, portanto, novas narrativas sobre a ditadura, evidenciando a violência das açôes econômicas 
do regime de exceção em articulação com empresas privadas. Com isso, mobilizaram diferentes noçóes de gravidade, de modo a ajustá-las às várias experiências históricas, de sensibilidades e sofrimentos.

O movimento de contextualização da "verdade" e dos direitos humanos, associado à habilitação política de "vítimas", foi o motor do comissionismo. Seus operadores sistematizaram, reiteradas vezes, argumentos de "profilaxia" da "verdade" e da memória, ressaltando equivalências entre as açóes do período ditatorial e as práticas governamentais depois da redemocratização do país. Ao fazê-lo sem modulaçóes analíticas, supondo uma firme linha de continuidade entre passado e presente, as comissóes negligenciaram fronteiras importantes entre o tempo e as circunstâncias da violência. Por outro lado, instigaram o olhar para a ditadura e a democracia a partir de um novo e necessário ângulo, atento às articulaçóes entre os poderes estatal e econômico no que diz respeito às violaçóes de direitos humanos.

\section{Notas}

1 Comissóes da verdade são corpos sem caráter jurídico que se difundiram a partir dos anos de 1980 em países recém egressos de regimes autoritários e guerras civis. Embora as comissóes da verdade variem consideravelmente com os contextos políticos e sociais a que se aplicam, em geral envolvem sessóes públicas ou privadas de testemunho com pessoas identificadas como vítimas de violaçóes de direitos humanos por agentes de força de regimes passados ou milícias privadas (com ou sem articulação com governos). Ao final de seu mandato, elas devem produzir um relatório final que apresente uma narrativa abrangente sobre a experiência repressiva no país durante o período reconhecido como autoritário ou guerreiro.

2 Os fóruns vários de interlocução entre sociedade e Estado em geral não contemplam a possibilidade de expressão emotiva, a não ser, em tribunais, quando domesticada pela retórica jurídica. No mais, as manifestaçôes de dor e sofrimento pertencem a domínios extraestatais. Uma das novidades institucionais das comissóes da verdade foi justamente a fixação de um lugar institucional para as emoçóes - não quaisquer emoções de quaisquer atores, é certo, mas aquelas que representam um certo "trauma social" que se quer conhecer ou construir pela voz das "vítimas" e reparar.
As aspas são para indicar expressóes correntes entre comissionários entrevistados para esta pesquisa.

3 Wilder Taylor é membro do Instituto de Estudios Legales e Sociales do Uruguay e a comissão em questão é a Comissão Investigativa sobre a Situação das Pessoas Desaparecidas e suas Causas.

4 Para um levantamento sistemático da composição de comissóes da verdade no mundo, ver Hayner (2011).

5 Sobre a construção da categoria de vítima, associada à categoria médica e social do trauma, ver Fassin e Rechtman (2007).

6 Embora muitíssimo relevantes na história transicional do Brasil, os movimentos de familiares e militantes por memória, verdade e justiça escapam ao recorte deste artigo.

7 Cabe assinalar, por exemplo, que a Comissão da Verdade do Pará, instalada em março de 2016, estabeleceu uma rotina intensa de trabalho em período posterior à conclusão desta pesquisa - que seguramente a incluirá em desdobramentos futuros.

8 A saber: Comissão Estadual da Verdade "Paulo Stuart Wright” (SC), Comissão Estadual da Verdade do Paraná “Teresa Urban” (PR), Comissão Estadual da Verdade do Rio Grande do Sul (RS), Comissão Estadual da Verdade do Rio de Janeiro (RJ), Comissão da Verdade do Estado de São Paulo "Rubens Paiva" (SP), Comissão Estadual da Verdade e da Preservação da Memória do Estado da Paraíba (PB), Comissão Estadual da Verdade da Bahia (BA), Comissão Estadual da Memória e Verdade "Dom Helder Câmara" (PE), Comissão Estadual da Verdade do Amapá (AP).

9 Como se verá na última seção deste artigo, o contraponto de perspectivas entre os níveis federal e estadual não foi rígido. Isto é, comissões estaduais não rejeitaram as categorias de graves violaçóes de direitos humanos da CNV, a qual, por sua vez, também se aproximou, por meio de seus grupos de trabalho, de pautas que ganharam protagonismo local.

10 O cálculo é aproximado porque há variações (novas indicações e resignações) depois da nomeação e posse de membros.

11 A listagem que se segue considera todas as quinze comissóes estaduais, inclusive as que não foram estudadas em profundidade neste trabalho. As informaçóes foram reunidas com base em consultas às próprias comissóes, pesquisas em relatórios parciais e finais e redes sociais.

12 A noção de representação evocada por comissionários não cumpre trâmites formais de autorização pela po- 
pulação de supostos representados. Comissionários tendem a lidar com o conceito de maneira simbólica e, claro, disputam esse simbolismo. Na última seção do artigo, será abordada a mais importante querela sobre quem seriam os "verdadeiros" representantes.

13 No caso da comissão paulista, seu presidente orquestrou uma situaçáo de fato radicalmente destoante de seus contornos formais, assemelhado ao de comissóes legislativas em geral. A comissão foi sobretudo conduzida por assessores não parlamentares historicamente ligados à causa dos desaparecidos políticos, tendo sido eles próprios afetados pela violência da ditadura. A eles coube a principal marca simbólica da comissão.

14 Os perfis "membros de governo e sociedade civil" não são estáticos, mas delimitam distinçóes de ocasião.

15 A categoria "afetados" aqui designa estritamente pessoas que foram objeto de violência por agentes do Estado, familiares de pessoas mortas ou desaparecidas também por forças do regime e pessoas que tenham sido constrangidas ao exílio ou impedidas de exercer sua vida profissional em razão de perseguição política. Embora eu reconheça que a afetação por um regime que limitou severamente as liberdades civis e políticas de toda a população possa ser descrita com base em outros enquadramentos, meu corte metodológico se restringe ao conjunto descrito de afetaçóes mais diretas. É sobre esse grupo de pessoas que se concentrarão as disputas de legitimidade abordadas na quarta seção deste artigo.

16 A depender dos arranjos políticos locais, as comissóes foram criadas por leis, decretos do Executivo e resoluçôes do Legislativo, o que teve impacto sobre suas rotinas de funcionamento. As comissóes criadas por leis tenderam a ter mais autonomia do que aquelas que resultaram de decretos.

17 A clivagem entre historiadores e juristas foi a mais significativa, associada a diferentes concepçóes de "verdade": histórica - dedicada à narrativa abrangente de um período histórico - e jurídica - concentrada em casos individuais e dirigida a possíveis desdobramentos judiciais dos casos.

18 Após seguidas tentativas, náo consegui contato para entrevista em profundidade com membro da Comissão da Verdade de Goiás, única que minha equipe de pesquisa e eu localizamos no Centro-Oeste.

19 O Transitional Justice Collaborative é composto por pesquisadores das Universidades de Oxford, Minnesota e Harvard, que buscam mapear os principais mecanismos de justiça de transiçáo mobilizado em 108 transições democráticas em 86 países, entre 1970 e 2012.
20 Sua metodologia de análise considera um elenco de indicadores que comporiam uma comissão de verdade ideal: a prática de testemunhos, a publicidade concedida a eles, o encorajamento à participaçáo, a produção de um relatório final de atividades e sua a publicidade, a publicação do nome de violadores de direitos e a demanda por processos judiciais.

21 É importante notar que essa perspectiva não é endossada por muitos observadores da CNV. Ainda não existe crítica sistemática organizada em trabalhos acadêmicos, mas alguns artigos de opiniáo publicados em veículos de grande e pequena circulação acompanham a insatisfaçáo com a "opacidade" da CNV, manifesta por familiares de vítimas e comitês de memória, verdade e justiça em carta pública veiculada de 16 de julho de 2013. A título de exemplo, Bernardo Kucinski publicou em 9 de setembro de 2012 um artigo em $O$ Estado de São Paulo em que questionou, entre outras coisas, a praxe de "portas fechadas" da CNV. Sua avaliação sobre a publicidade de rotinas da CNV colide com o parecer elogioso de Kathryn Sikkink.

22 A título de exemplo: "a ditadura na Argentina é uma coisa que os argentinos entendem como uma coisa que foi negativa para a sociedade argentina. $\mathrm{Na}$ nossa sociedade, muita gente acha que o golpe militar foi preventivo" (comissionário de Pernambuco); "Os países da América do Sul, principalmente Chile, Peru, Argentina, Uruguai, todos. Assim que a ditadura deixou de existir, em pouco tempo foi criada as Comissóes. Aqui no Brasil demorou tempo demais" (comissionário do Rio de Janeiro); "Na Argentina, a sociedade tem o tema da ditadura muito presente. No Brasil, isso náo aconteceu da mesma forma. Mas aqui, diferente de lá, não teve ruptura, né? Tudo foi negociado, uma eterna transição" (comissionária do Rio de Janeiro); "Na Argentina começaram muito antes. [...]. A gente demorou muito, demais" (comissionário de Santa Catarina).

23 É evidente a expansão de comissóes da verdade para âmbitos que excedem o escopo deste artigo, a exemplo da Comissão da Verdade da Escravidáo Negra, criada pelo Conselho Federal da Organização dos Advogados do Brasil.

24 Mais precisamente, conforme informaçáo prestada pelo sistema eletrônico do Serviço de Informação ao Cidadáo, em fevereiro de 2016, os gastos totais com medidas compensatórias da Comissão Especial de Mortos e Desaparecidos foi de $\mathrm{R} \$ 39.986 .150,00$ e, da Comissão de Anistia, de R \$7.965.210.635,37.

25 No caso da CNV, após importantes dissensos internos, a recomendação de revisão da Lei de Anistia não 
recebeu a validação de todos os comissionários. Um deles decidiu não se pronunciar a este respeito. De todo modo, o acordo da maioria dos membros colidiu com os termos mais estritos da lei de criação do órgáo.

26 Em entrevista, o comissionário baiano afirma: "Depois das manifestaçóes de junho, havia pessoas que diziam que tinham se posicionado contra elas e dizendo que queriam a volta dos militares. Quando essas pessoas eram confrontadas com informaçóes sobre o regime militar, revisavam sua opinião". Segundo o comissionário de Santa Catarina, "A gurizada não sabe. Para não acontecer de novo, a gente não pode esquecer. E para não esquecer tem que contar, tem que estar na história". Para a comissionária de Minas Gerais, "A verdade é para que não aconteça nunca mais". Conforme o desejo do comissionário da Paraíba: "Que a juventude se informe e fique sendo uma defesa para regimes ditatórios". Para a comissionária do Rio de Janeiro: "Se nós não falarmos sobre isso, vai cair no esquecimento e corre o risco de repetir. [...] Para evitar as violaçóes futuras eu não consigo imaginar uma outra forma que não seja de fomentar a memória como uma política pública. [...] Para não errar, as pessoas têm que saber o que foi errado".

27 Em todas as entrevistas, os comissionários transitam sem mediaçóes entre as violências ocorridas em períodos de ditadura e de democracia. A única ressalva foi pontuada pelo comissionário de São Paulo, que afirmou que é necessário "entender melhor a ditadura" e que não é possível "fazer uma transposiçấo automática, da ditadura para a democracia”. Na ditadura, afinal, tinha a "resistência política". E continua: "não que na ditadura não houvesse esse tipo de genocídio, mas são tipificaçóes completamente diferentes".

28 Trata-se de Amarildo Dias de Souza, ajudante de pedreiro que foi assassinado em julho de 2013 por policiais militares na sede da Unidade de Polícia Pacificadora, na Rocinha, no Rio de Janeiro. Em 2014, as alusôes ao chamado "caso Amarildo" foram recorrentes nos eventos de descomemoração do golpe organizados por comissóes e comitês de memória, verdade e justiça em todo país.

29 Discurso de Dilma Rousseff em 16 de maio de 2012, disponível em www2.planalto.gov.br.

30 A escolha pelo formato de uma comissáo legislativa em São Paulo foi, segundo o comissionário fundador, por conta do que se supunha ser uma conjuntura desfavorável no governo estadual. Ainda assim, foram enfrentadas resistências na aprovação da comissão na Assembleia Legislativa.
31 O comissionário faz ressalva a uma única comissionária, que foi advogada de presos políticos e tinha um perfil mais próximo ao que lhe parecia desejável.

32 No Amapá, foram 40 testemunhos públicos; na Bahia, 86; na Paraíba, 81; no Paraná, 137; em Pernambuco, 107; no Rio de Janeiro, 153; no Rio Grande do Sul, 70. Apenas Santa Catarina e Minas Gerais não chamam atenção, com apenas 13 e 1 testemunhos, respectivamente. As comissōes, em geral adotaram o princípio das portas abertas da CRP, mas não recusaram o protocolo da CNV de tornar o testemunho secreto mediante a solicitação de depoentes que náo desejavam a exposição pública. Foi assim que Amapá conduziu 6 testemunhos fechados; Bahia, 7; Minas Gerais, 6; Rio de Janeiro, 52; Rio Grande do Sul, 11. Essas informações foram reunidas de diferentes formas: consultas a comissionários, pesquisa nos relatórios finais das comissóes e em redes sociais.

33 As aspas se justificam porque uso o conceito como categoria nativa. Em sentido estrito, camponeses também são trabalhadores, mas figuram, na fala dos comissionários, em categoria à parte.

34 E, posteriormente, na comissão do Pará, que não participou desta pesquisa.

35 O que o comissionário do Amapá tem em vista é a construção de autoestrada que atravessou o território do estado em terras ocupadas por populaçóes indígenas.

36 Em linha com a praxe das comissóes da verdade no mundo, apenas os crimes considerados políticos compunham o repertório de investigação da CNV.

\section{BIBLIOGRAFIA}

ABRAÃO, Paulo \& TORELLY, Marcelo. (2011), “O programa de reparaçóes como eixo estruturante da justiça de transição no Brasil”, in Félix Reátegui, Manual de justiça de transiçâo para a América Latina. Brasília/Nova York, Comissão de Anistia, Ministério da Justiça/Centro Internacional para a Justiça de Transição, pp. 473-516.

ACUÑA, C. H. \& PRZEWORSKI, A. (1995), Juicio, castigo y memorias: derechos humanos y justicia en la politica argentina. Buenos Aires, Nueva Visión.

ASTOLFI, Roberta \& LAGATTA, Pedro. (2015), "Os desafios para caracterizar o conceito de graves violaçôes de direitos humanos a partir 
da análise dos julgamentos de deslocamento de competência de 2005 a 2014". Revista Liberdades, maio-ago.

BORAINE, Alex. (2000), A country unmasked. Oxford, Oxford University Press.

FASSIN, Didier \& RECHTMAN, Richard. (2007), The empire of trauma: an inquiry into the condition of victimhood. Princeton, Princeton University Press.

GIBNEY, Mark (org.). (2008), The age of apology: facing up to the past. Philadelphia, University of Pennsylvania Press.

HAYNER, Priscilla. (2011), Unspeakable truths: transitional justice and the challenge of truth commissions. Nova York, Routledge.

HOPGOOD, Stephen. (2013), The endtimes of human rights. Nova York, Cornell University Press.

HUNGTINTON, Samuel P. (1994), A terceira onda: a democratização no final do século XX. São Paulo, Ática.

KRITZ, Neil. (2004), Transitional justice: how emerging democracies reckon with former regimes. Washington, D.C., United States Institutes of Peace Press, 2004.

MOYN, Samuel. (2010), The last utopia. Cambridge, Harvard University Press.

NEIER, Aryeh. (2012), The international human rights movement: a history. Princeton, Princeton University Press.

ORENTLICHER, D. F. (1991), "Settling accounts: the duty to prosecute human rights violations of a prior regime". Yale Law Journal, 100 (8): 2537-2615.

ROMANELLI, San. (2015), "Comissāo Nacional da Verdade - modo de usar: abecedário das reparaçôes". Revista Insight Inteligência, 69: 114127, abr.-maio-jun.

ROSANVALLON, Pierre. (2009). La legitimidad democrática: imparcialidad, reflexividad, proximidad. Buenos Aires, Manantial.

SIKKINK, Kathryn. (1995). Justice Cascade: how human rights prosecutions are changing world politics. Nova York/Londres, W. W. Norton \& Company.

SIKKINK, Kathryn \& MARCHESI, Bridget. (2015). "Nothing but the truth: Brazil's truth commission looks back". Foreign Affairs, 26, fev. Disponível em http://www.foreignaffairs.com/ articles/143180/kathryn-sikkink-and-bridget-marchesi/nothing-but-the-truth?cid=nlc-foreign_affairs_this_week-030515-nothing_but_ the_truth_5-030515\&sp_mid=48163663\&sp_ rid=aWV2YUB1ZmwuZWR1S0.

SMALL, Mario Luis. (2009), "How many cases do I need? On science and the logic of case selection in field based-research". Ethnography, 10 (1): 5-38.

TUTU, Desmond. (1999), No future without forgiveness. Londres, Rider. 


\section{DIREITOS HUMANOS E DEMOCRACIA: A EXPERIÊNCIA DAS COMISSÓES DA VERDADE NO BRASIL}

\section{Cristina Buarque de Hollanda}

Palavras-chave: Comissôes de verdade; Justiça de transição; Direitos humanos; Democracia

O objetivo deste artigo é refletir sobre o fenômeno de proliferaçáo das comissóes da verdade no Brasil, enfocando os modos como a democracia e os direitos humanos são compreendidos. Baseio-me em pesquisa documental e entrevistas semiestruturadas com membros da Comissão Nacional da Verdade e de dez comissões sediadas em diferentes estados da federaçáo. Os comissionários convergem na expectativa de pedagogia cívica da "verdade" e na simbiose de significados entre democracia e direitos humanos. Por outro lado, há dois eixos de dissenso. O primeiro diz respeito à validade de seus princípios motores, isto é, a "verdade das vítimas" ou a "verdade imparcial". O segundo concerne às interpretaçóes sobre o que seriam "graves violaçôes de direitos humanos", umas afins à prática do direito internacional e outras próximas às sensibilidades locais. Embora salientes, os contrapontos propostos não são rígidos e apresentam importantes matizes.

\section{HUMAN RIGHTS AND \\ DEMOCRACY: NATIONAL TRUTH COMMISSIONS' EXPERIENCE IN BRAZIL}

\section{Cristina Buarque de Hollanda}

Keywords: Truth commissions; Transitional justice; Human rights; Democracy

This article aims to reflect on the proliferation phenomenon of national truth commissions in Brazil, highlighting the ways in which democracy and human rights are understood. I base this work on documentary research and semistructured interviews with members of the National Truth Commissions and ten other commissions situated in other states of Brazil. The commissioners converge in expecting a civic pedagogy of "truth" and in their symbiosis of significations of democracy and human rights. On the other hand, there are two axes of dissent. The first concerns the validity of its main motivators, i.e., the "victims' truth" or the "impartial truth". The second comprises the interpretations of the term "grave human rights violations", some partial to the practice of international right, and others, to local sensibilities. Although prominent, the proposed counterpoints are not rigid and present many important shades.

\section{DROITS DE L'HOMME ET \\ DÉMOCRATIE : L'EXPÉRIENCE DES COMMISSIONS DE LA VÉRITÉ AU BRÉSIL}

Cristina Buarque de Hollanda

Mots-clés: Commissions la vérité; Justice transitionnelle; Droits de l'Homme; Démocratie

Le but de cet article est de réfléchir sur le phénomène de la prolifération des commissions de la vérité au Brésil, en se concentrant sur la manière dont la démocratie et les droits de l'homme sont appréhendés. Nous nous sommes basés sur la recherche documentaire et des entretiens semi-structurés avec des membres de la Commission Nationale de laVérité et de dix commissions qui siègent dans les différents États de la Fédération. Les commissionnaires convergent sur l'attente en matière de pédagogie civique de la "vérité " et la symbiose des significations entre la démocratie et des droits de l'homme. En revanche, il existe deux axes dissidents. Le premier concerne la validité de ces principes, c'est-à-dire, la "vérité des victimes " ou la " vérité impartiale ». Le deuxième concerne les interprétations la définition de "violations graves des droits de l'homme ", certaines proches de la pratique du droit international et d'autres, des sensibilités locales. Bien que qu'apparents, les contrepoints proposés ne sont pas rigides et présentent des nuances importantes. 